\title{
In-vitro ANTICANCER ACTIVITY, ANTIMICROBIAL AND In-silico STUDIES OF NAPHTHYL PYRAZOLE ANALOGUES
}

\author{
A. B. Senthieel Khumar, K. Naveen Kumar, C. Raja and M.R.Ezhilarasi* \\ Department of Chemistry, Karpagam Academy of Higher Education, Coimbatore- 21, \\ Tamil Nadu, India. \\ *E-mail: mrezhilarasi@gmail.com
}

\begin{abstract}
A new sequence of new pyrazoline derivatives (5a-5h) was synthesized from 2-naphthylstyryl chalcone to react with hydrazine hydrate in the presence of n-butyric acid using the cyclization method. Synthesized compounds (5a-5h) chemical structure was elucidated by FT-IR, Proton and Carbon NMR Spectral data and CHN analysis. All the compounds (5a-5h) were subjected to in-vitro biological activity using disk diffusion method. The electronwithdrawing fluoro substituted compound $\mathbf{5 b}$ was better antibacterial activity against the bacterial strain of Pseudomonas aeruginosa and also the electron-withdrawing compound like bromo substitution 5d was excellent activity against bacterial strain of Escherichia coli and the fluoro substituted compound $\mathbf{5 b}$ was shown excellent activity against the gram-positive bacterial strain of Streptococcus pyogenes which was compared with the standard drug (Ciprofloxacin). The fluoro substituted compound $\mathbf{5 b}$ shown good antifungal activity against candida albicans. After that synthesized compounds (5a-5h) were subjected to molecular docking studies using bacterial protein and breast cancer protein. From this result, the synthesized compounds (5a-5h) have a high binding affinity score compared with the standard drug ciprofloxacin. Based on the high binding affinity score, compound $\mathbf{5 b}$ was subjected to in-vitro anticancer activity by MTT assay method against MDA MB-231 Cell line. From this result, the fluro substituted compound $\mathbf{5 b}$ showed good activity at low concentration $(6.25 \mu \mathrm{g} / \mathrm{ml})$. The LC 50 value of this compound $\mathbf{5 b}$ is $27.76 \pm 0.003 \mu \mathrm{g} / \mathrm{ml}$. Compounds $\mathbf{5 b}$ and $\mathbf{5 h}$ are the most important compound and there is only needed to develop new antibacterial agents. The compounds (5a-5h) are also subjected to ADME (druglikness) property using Osiris program, a result that $\mathbf{5 c}$ has the best druglikness property and 0.51 drug score with $32.67 \AA$ total polar surface area.
\end{abstract}

Keywords: Conventional method, 2-Naphthylstyryl Ketone, n-Butyric acid, Hydrazine hydrate, Antimicrobial activity; Anticancer activity(MDA MB-231 Cell line).

(C) RASĀYAN. All rights reserved

\section{INTRODUCTION}

For centuries, Cancer has been prevailing as the most serious disease and its incidence is rising day-today in the world. ${ }^{1-2}$ The literature review is clearly explained more than $90 \%$ of cancer patients die due to chronic tumor metastases. Despite the presence of a large number of anticancer drugs, there is no currently available agents can destroy completely cancer cells without harming normal tissues. ${ }^{3-5}$ The development of a new anticancer agent's future is very important in the major engrossment in many industrial research laboratories and academics across the world to develop more potent molecules with higher explicitness and minimized toxicity. ${ }^{6,7}$

Heterocyclic compounds particularly those with oxygen, nitrogen and sulphur atoms have been identified to have the most comprehensive spectrum of biological activities. ${ }^{8}$ In the synthesis of hetetocyclic compounds, chalcones are used as an intermediate and it should have good biological activity as well as it plays an important role in medicinal chemistry and drug discovey. ${ }^{9-11}$ The pyrazoline derivatives are the most important classes of the heterocyclic compound and it is a versatile lead molecule in the agrochemical and pharmaceutical field. The pyrazoline derivatives have various biological activities such as antimicrobial ${ }^{12}$, antitumor ${ }^{13}$, antibacterial ${ }^{14}$, anti-inflammatory ${ }^{15}$, anticancer ${ }^{16}$, antidiabetic ${ }^{17}$, pharmacological ${ }^{18}$, free radical scavenging ${ }^{19,20}$ activities. Among the reported activities, it is important to 
RASĀYAN J. Chem.

Vol. 13 | No. 2 |1199-1214| April - June | 2020

note that pyrazoline is not only useful in the treatment of various cancer types, including brain, bone, mouth, esophagus, stomach, liver, bladder, pancreas, cervix, lung, breast, colon, rectum and prostate cancers, but some of them act as cancer chemopreventive agents. ${ }^{21}$ Most of the pyrazole compounds have a lot of industrial applications and anticorrosive inhibition property. ${ }^{22}$

On the other hand, pyrazoline derivatives were carried out of the focus of drug discovery; like the studies drug-ability and bioactivity of the compounds. The concept of drug-ability is defined as the prospect to find a compound with high potency, drug-like properties, as well as measured properties concerning undesirable side effects, metabolism, and intestinal absorption. It was observed that about $30 \%$ of oral drug fail in development due to poor pharmacokinetics studies. ${ }^{23}$ It is worth to note that lack of in vivo effectiveness of a drug candidate might be due to poor physicochemical properties of the drug candidate itself. $^{24}$ Also biding activity can be predicted by studying whether the tested compounds are complementary with the binding sites on biological molecules in terms of topology, volume and physiochemical properties. ${ }^{25}$ That's to say, it is useful to estimate the probability that a molecule can bind a given protein with sufficient affinity to modify its activity. ${ }^{26}$ So, Computation screening of new compounds, ie in-silico prediction of druglikness and bioactivity, has been proved to be very important in the early stage of drug discovery to subject the most suitable compounds to further optimization and to find drug candidate for further clinical development. ${ }^{27,28}$

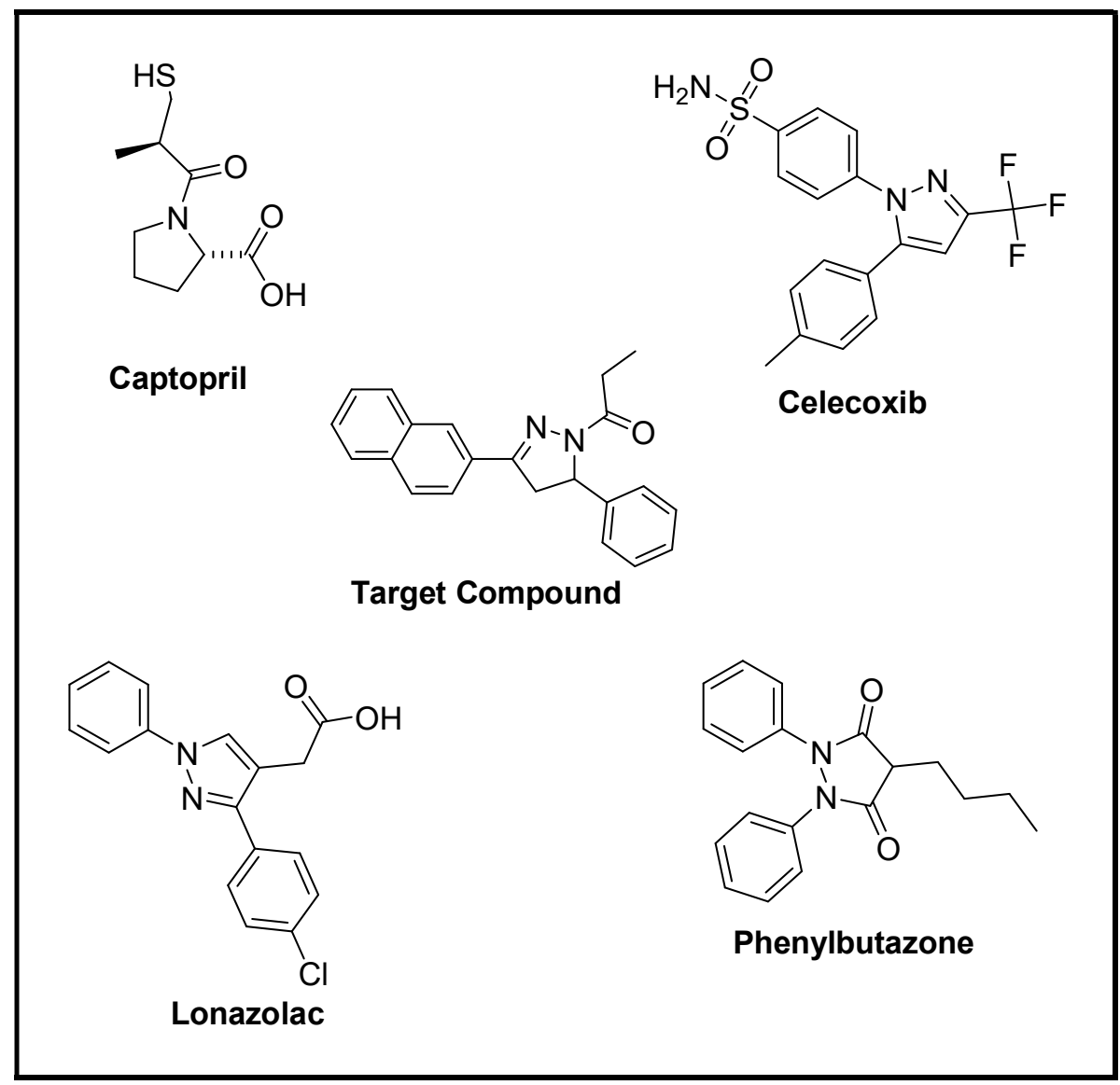

Fig.-1: The Structure of Some Drugs bearing the Pyrazole Moiety

Prompted by the aforementioned findings and in the continuation of our ongoing research in the field of design, synthesis, and biological evaluation of pyrazoline derivatives, herein we described the synthesis and spectral characterization of a new series of substituted pyrazoline as potential anticancer agents against (3,4-methylenedioxyamphetamine) MDA MB 231 Breast cancer cell line study by MTT (3-(4,5dimethyl thiazol-2-yl)-2,5-diphenyltetrazolium bromide)assay method. ${ }^{29-31}$ Molecular docking studies 
RASĀYAN J. Chem.

Vol. 13 | No. 2 |1199-1214| April - June | 2020

were carried out against bacterial proteins and breast cancer protein. Finally, the synthesized compounds were screened for antimicrobial activity against the disc diffusion method. New anticancer drugs are previously used in clinical research, some of the anticancer drugs are not efficiently and intolerable side effects ${ }^{32}$. Based on the above study, we need to development of new drugs against anticancer and antimicrobial activities. Therefore, we were led to identifying new approaches of pyrazoline derivatives as well as test the antimicrobial and anticancer activity.

\section{Chemicals and Reagents}

\section{EXPERIMENTAL}

All the chemicals were purchased from variable sources, used without purification. The synthesized compounds were checked by TLC on Silica gel plates (E-Merk, Mumbai, India). The melting points of the synthesized compounds are carried out by an open capillary method and it was uncorrected. The FTIR spectrum was recorded in $\mathrm{KBr}$ pellets on an FT-IR Shimadzu 8400s spectrometer in the range of 400$4000 \mathrm{~cm}^{-1}$. ${ }^{1} \mathrm{H}$ NMR and ${ }^{13} \mathrm{C}$ NMR spectra were recorded by Brucker $400 \mathrm{MHz}$ and Brucker $100 \mathrm{MHz}$ spectrometer (in $\delta \mathrm{ppm}$ ) using TMS as an internal standard. CHN analyses were recorded on the Perkin Elmer CHN analyzer. By adopting the literature precedent; chalcones (3a-3h) are prepared ${ }^{5}$.

\section{Synthesis of Pyrazoline Butanone Derivatives (5a-5h)}

Naphthyl Chalcones (3a-3h) $(0.01 \mathrm{~mol})$, hydrazine hydrate $(0.01 \mathrm{~mol})$, anhydrous sodium acetate $(0.01$ $\mathrm{mol})$ and Butyric acid (Propyl formic acid) $(20 \mathrm{ml})$ are taken in a round bottom flask and reaction mixture was refluxed until the products are formed. The reaction is monitored by TLC. The time required for the formation of various pyrazole is 6-9 hrs. The reaction mixture is poured into crushed ice and left overnight. The precipitate is separated by filtration, washed well with water, dried and the obtained solids are purified by recrystallization using rectified sprit which affords the title compounds $(5 \mathrm{a}-5 \mathrm{~h})$ in moderate yield. The experimental procedure was followed by the reference method. ${ }^{33}$

\section{Molecular Docking Study}

The molecular docking studies have been carried out using the Auto dock Tools (ADT) version 1.5.6 and Auto dock version 4.2.5.1 docking program ${ }^{5}$.

\section{Preparation of the Protein}

The bacterial protein and breast cancer protein were downloaded from Protein Data Bank with PDB id: $1 \mathrm{UAG}$ and 1OQA.

\section{Ligand Preparation}

2D structure of the target compounds is drawn using Chemdraw Ultra 8.0 (Chemoffice 2002). After Chem 3D Ultra 8.0 was used to convert the 2D structure into the 3D structure, and the energy is minimized using the semi-empirical AM1 method. All the structures are saved as pdb file format for input to ADT. Finally, all the ligand structures are saved as PDB file format to carry out molecular docking in Auto dock Vina.

\section{Grid Formation}

A grid box with a dimension of $40 \times 40 \times 40 \mathrm{~A}^{3}$ in $0.375 \mathrm{~A}$ spacing and centered on $30.473,47.997$, 9.563 has created around the binding site of protein using ADT. The center of the box was set at ligand center and grid energy calculations have been carried out.

\section{Docking Protocol}

The Auto dock calculation, are such as default parameters have been used and 10 docked conformations are generated for each compound. The energy calculation is done using genetic algorithms. The outputs are exported to Chimera 1.10 and discovery studio 4.5 for visual inspection of the binding modes and interaction of the compounds with amino acid residues in the active site. The procedure was followed by the literature method. ${ }^{34}$ 
RASĀYAN J. Chem.

Vol. 13 | No. 2 |1199-1214| April - June | 2020

\section{Pharmacological Activity}

\section{Antibacterial Screening}

The antibacterial screening for synthesized pyrazoline compounds was determined by the agar disk diffusion method against gram-positive bacterial strains of Staphylococcus aureus, Streptococcus pyogenes and gram-negative bacterial strains of Escherichia coli, Pseudomonasaeruginosa. The zone of inhibition was measured after $24 \mathrm{~h}$ incubation at $37^{\circ} \mathrm{C}$. The biological screening experimental procedure was adopted by the literature survey method. ${ }^{35-37}$

\section{Antifungal Screening}

The antifungal screening for synthesized pyrazoline compounds was determined by the agar disk diffusion method against Candida albicans strain. The zone of inhibition was measured after $24 \mathrm{~h}$ incubation at $37^{\circ} \mathrm{C}$.

\section{In-silico Druglikness Property}

ADME property is done by Osiris online software program. All synthesized compounds (5a-5h) subjected to druglikness property to predict the solubility, absorption, Lipinski rule violation, and surface area of the compounds. The compound which has molecular weight $\leq 500, \mathrm{n}-\mathrm{HA} \leq 10, \mathrm{n}-\mathrm{HD} \leq 5, \log \mathrm{P} \leq 5$ and Molar refractivity $\leq 140$ obey the Lipinski rule of five. Also, compounds have a polar surface area (7 to 200 ), solubility value and drug score (above 0.5 ). All the above properties are predicted with the help of the Osiris program.

\section{Anticancer Activity \\ MTT Assay}

MDA MB-231 (Human Breast Adenocarcinoma) cell was initially procured from National Centre for Cell Sciences (NCCS), Pune, India and maintained Dulbecco's modified eagle's medium, DMEM (Sigma Aldrich, USA).

The cell line was cultured in $25 \mathrm{~cm}^{2}$ tissue culture flask with DMEM supplemented with $10 \%$ FBS, Lglutamine, sodium bicarbonate (Merck, Germany) and an antibiotic solution containing: penicillin (100 $\mathrm{U} / \mathrm{ml})$, Streptomycin $(100 \mu \mathrm{g} / \mathrm{ml})$, Streptomycin $(100 \mu \mathrm{g} / \mathrm{ml})$, and Amphotericin B $(2.5 \mu \mathrm{g} / \mathrm{ml})$. Cultured cell lines were kept at $37^{\circ} \mathrm{C}$ in a humidified $5 \% \mathrm{CO}_{2}$ incubator (NBS Eppendorf, Germany).

The viability of cells was evaluated by direct observation of cells by an inverted phase-contrast microscope and followed by MTT assay method.

\section{Cells Seeding in 96 Well Plate}

Two days old confluent monolayer of cells trypsinized and the cells were suspended in $10 \%$ growth medium, $100 \mu 1$ cell suspension $\left(5 \times 10^{4}\right.$ cells/well) was seeded in 96 well tissue culture plate and incubated at $37^{\circ} \mathrm{C}$ in a humidified $5 \% \mathrm{CO}_{2}$ incubator.

\section{Preparation of Compound Stock}

$1 \mathrm{mg}$ of the sample was weighed and dissolved in $1 \mathrm{ml}$ DMEM using a cyclomixer. The sample solution was filtered through $0.22 \mu \mathrm{m}$ Millipore syringe filter to ensure sterility.

\section{Anticancer evaluation}

After $24 \mathrm{~h}$ the growth medium was removed, freshly prepared each compound in 5\% DMEM was five times serially diluted by two-fold dilution $(100,50,25,12.5,6.25 \mu \mathrm{g}$ in $500 \mu \mathrm{l})$ of $5 \%$ DMEM and each concentration of $100 \mu \mathrm{l}$ was added in triplicates to the respective wells and incubated at $37{ }^{\circ} \mathrm{C}$ in a humidified $5 \% \mathrm{CO}_{2}$ incubator. Non treated control cells were also maintained ${ }^{5}$.

\section{Anticancer Assay by MTT Method}

$15 \mathrm{mg}$ of MTT (Sigma, M-5655) was reconstituted in $3 \mathrm{ml}$ PBS until completely dissolved and sterilized by filter sterilization. After $24 \mathrm{~h}$ of the incubation period, the sample content in wells was removed and 30 $\mu 1$ of reconstituted MTT solution was added to all test and cell control wells, the plate was gently shaken 
RASĀYAN J. Chem.

Vol. 13 | No. 2 |1199-1214| April - June | 2020

well, then incubated at $37{ }^{\circ} \mathrm{C}$ in a humidified $5 \% \mathrm{CO}_{2}$ incubator for $4 \mathrm{~h}$. After the incubation period, the supernatant was removed and $100 \mu 1$ of MTT solubilization solution (DMSO, Sigma Aldrich, USA) was added and the cells were mixed gently by pipetting up and down to solubilize the formazan crystals. The absorbance values were measured by using a microplate reader at a wavelength of $540 \mathrm{~nm}^{38}$.

The percentage of growth incubation was calculated using the following formula:

$$
\% \text { of Viability }=[\text { Mean OD Samples X 100] / [ Mean OD of Control Group }]
$$

\section{RESULTS AND DISCUSSION}

\section{Synthesis and Characterization of Pyrazoline Analogs}

The pyrazoline derivatives (5a-5h) were synthesized from 2-naphthylstyryl chalcone react with Hydrazine hydrate in the presence of propyl formic acid using the cyclization process via the conventional method. Before that, the 2-naphthyl styryl chalcone derivatives (3a-3h) were synthesized from 2-naphthylstyryl ketone react with different substituted aromatic aldehydes in the presence of a strong base. The synthetic route of pyrazoline derivatives represented in Scheme-1.

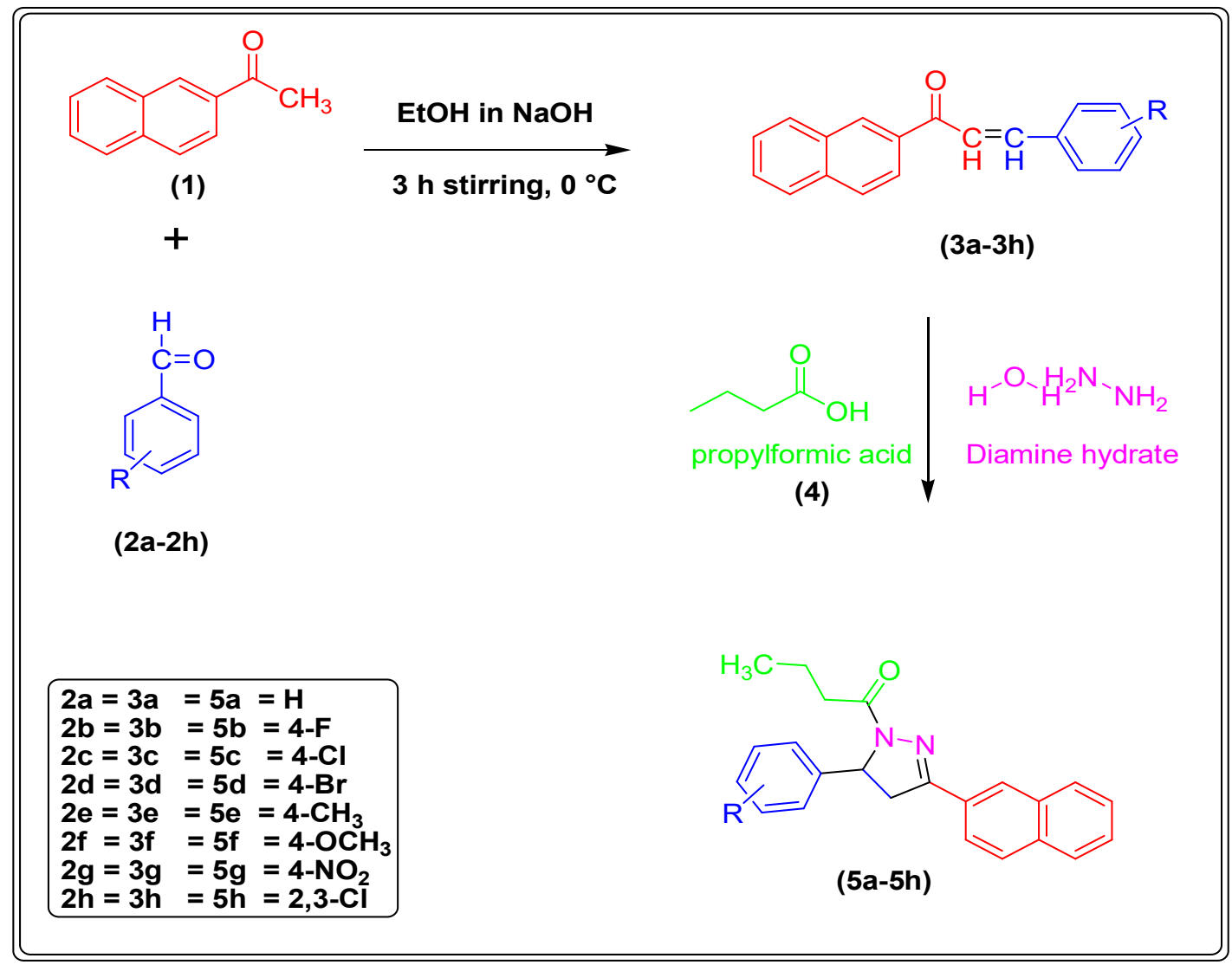

\section{Spectral Characterization}

Scheme-1: Synthetic Route of the Isolated Compounds (5a-5h)

The isolated compound's chemical structures were elucidated using FT-IR, ${ }^{1} \mathrm{H}$ NMR, ${ }^{13} \mathrm{C}$ NMR and elemental analysis. The compound 3a was confirmed by FT-IR spectral data showing the sharp band at $1660.70 \mathrm{~cm}^{-1}$ which is indicate the presence of carbonyl group $(\mathrm{C}=\mathrm{O})$. The aromatic $\mathrm{CH}$ stretching frequency was observed sharp peak at $3059.10 \mathrm{~cm}^{-1}$. The aromatic $\mathrm{C}=\mathrm{C}$ stretching frequency was observed at $1593.20 \mathrm{~cm}^{-1}$. Other chalcone derivative's physical and chemical properties are shown in Table-1. The pyrazoline derivatives (5a-5h) chemical structures were confirmed using FT-IR spectral data. From this result, compound 5a shows the strong absorption frequency at $1658.78 \mathrm{~cm}^{-1}$, which indicates the presence of a carbonyl group of butane moiety. The $\mathrm{C}=\mathrm{N}$ stretching frequency was observed 
RASĀYAN J. Chem.

Vol. 13 | No. 2 |1199-1214| April - June | 2020

at $1402.25 \mathrm{~cm}^{-1}$. The aromatic $\mathrm{CH}$ stretching frequency was observed at $3140.11 \mathrm{~cm}^{-1}$. Other compounds IR results were shown in Table-2.

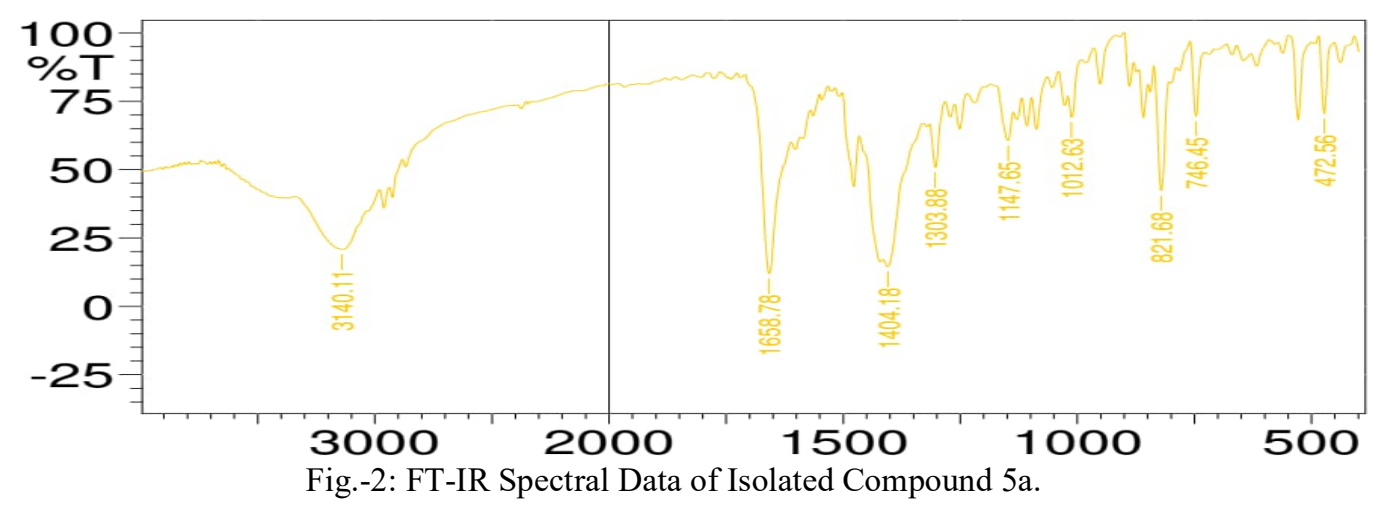

Table-1: FT-IR Spectral Data of Synthesized Compound (3a-3h) $\mathrm{cm}^{-1}$

\begin{tabular}{c|c|c|c|c}
\hline Entry & $\mathrm{C}=\mathrm{O}$ & $\mathrm{C}=\mathrm{C}$ & $\mathrm{Ar}-\mathrm{CH}$ & Others \\
\hline $3 \mathrm{a}$ & 1660.7 & 1593.20 & 3059.10 & $819.75,752.24$ \\
\hline $3 \mathrm{~b}$ & 1624.06 & 1579.70 & 3068.75 & $823.60,752.24$ \\
\hline $3 \mathrm{c}$ & 1664.57 & 1597.06 & 3059.10 & $819.25,756.10,705.95$ \\
\hline $3 \mathrm{~d}$ & 1651.07 & 1600.92 & 3051.39 & $815.89,750.31,709.80,680.87$ \\
\hline $3 \mathrm{e}$ & 1651.07 & 1602.85 & 3051.39 & $750.31,706.96,813.36$ \\
\hline $3 \mathrm{f}$ & 1654.92 & 1597.06 & 3051.39 & $815.83,759.95,746.45$ \\
\hline $3 \mathrm{~g}$ & 1660.71 & 1600.92 & 3055.24 & $813.96,752.24$, \\
\hline $3 \mathrm{~h}$ & 1658.87 & 1589.32 & 3067.41 & $813.73,759.67$ \\
\hline
\end{tabular}

Table-2: FT-IR Spectral Data of Isolated Compound $(5 \mathrm{a}-5 \mathrm{~h}) \mathrm{cm}^{-1}$

\begin{tabular}{c|c|c|c}
\hline Entry & $\mathrm{C}=\mathrm{O}$ & ${\mathrm{C}=\mathrm{N}^{1}}^{1}$ & Ar-CH \\
\hline $5 \mathrm{a}$ & 1658.78 & 1402.25 & 3140.11 \\
\hline $5 \mathrm{~b}$ & 1664.57 & 1400.32 & 3155.54 \\
\hline $5 \mathrm{c}$ & 1658.78 & 1404.18 & 3140.11 \\
\hline $5 \mathrm{~d}$ & 1652.14 & 1407.13 & 3110.14 \\
\hline $5 \mathrm{e}$ & 1659.70 & 1403.38 & 3115.41 \\
\hline $5 \mathrm{f}$ & 1655.42 & 1405.89 & 3119.82 \\
\hline $5 \mathrm{~g}$ & 1651.92 & 1401.01 & 3142.33 \\
\hline $5 \mathrm{~h}$ & 1654.89 & 1402.04 & 3188.79 \\
\hline
\end{tabular}

The Proton NMR spectrum of compound 5a shows the three doublets of doublet 3.25, 3.85 and 5.59ppm respectively, the doublet of a doublet at in the downfield region of the $5.59 \mathrm{ppm}$ and it has the coupling constant value $\mathrm{J}_{5 \mathrm{a}, 4 \mathrm{a}}=11.6 \mathrm{~Hz}$ and $\mathrm{J}_{5 \mathrm{a}, 4 \mathrm{~b}}=4.4 \mathrm{~Hz}$, which indicates the presence of $\mathrm{H}-5 \mathrm{a}$ proton of pyrazole moiety. The H-4a proton of the pyrazole moiety exhibited the downfield shift that appeared at the doublet of a doublet at $3.25 \mathrm{ppm}$ and the coupling constant value $\mathrm{J}_{4 \mathrm{a}, 4 \mathrm{~b}}=17.4 \mathrm{~Hz}$ and $\mathrm{J}_{4 \mathrm{a}, 5 \mathrm{a}}=4.2 \mathrm{~Hz}$. The H- $4 \mathrm{~b}$ proton of pyrazole moiety in appeared the doublet of a doublet at $3.85 \mathrm{ppm}$ and the coupling constant value $\mathrm{J}_{4 \mathrm{~b}, 4 \mathrm{a}}=17.2 \mathrm{~Hz}$ and $\mathrm{J}_{4 \mathrm{~b}, 5 \mathrm{a}}=12 \mathrm{~Hz}$. The aromatic protons have appeared at the range between $7.19-8.09 \mathrm{ppm}$. The methyl group of butane moiety in pyrazoline compound appears triplet at the range is $1.008-1.026 \mathrm{ppm}$. The methylene proton of butane moiety in the pyrazoline compound exhibited a multiplet at in the range of $2.75 \mathrm{ppm}-2.90 \mathrm{ppm}$ is due to the presence of neighboring protons of butane moiety. Another $\mathrm{CH}_{2}$ proton of butane moiety in pyrazoline compound exhibits the multiplet at in the range of $1.725 \mathrm{ppm}-1.780 \mathrm{ppm}$. The compounds (5a-5h) Proton-NMR spectral values are shown in Table-3.From the proton NMR spectral studies of the synthesized compound; the structure has been unambiguously confirmed. 
RASĀYAN J. Chem.

Vol. 13 | No. 2 |1199-1214| April - June | 2020

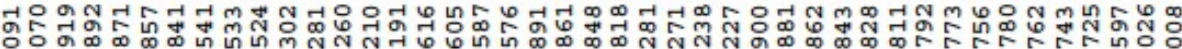

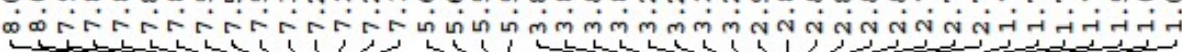

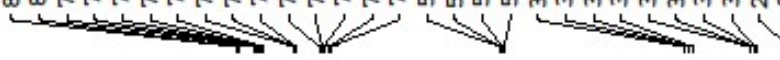

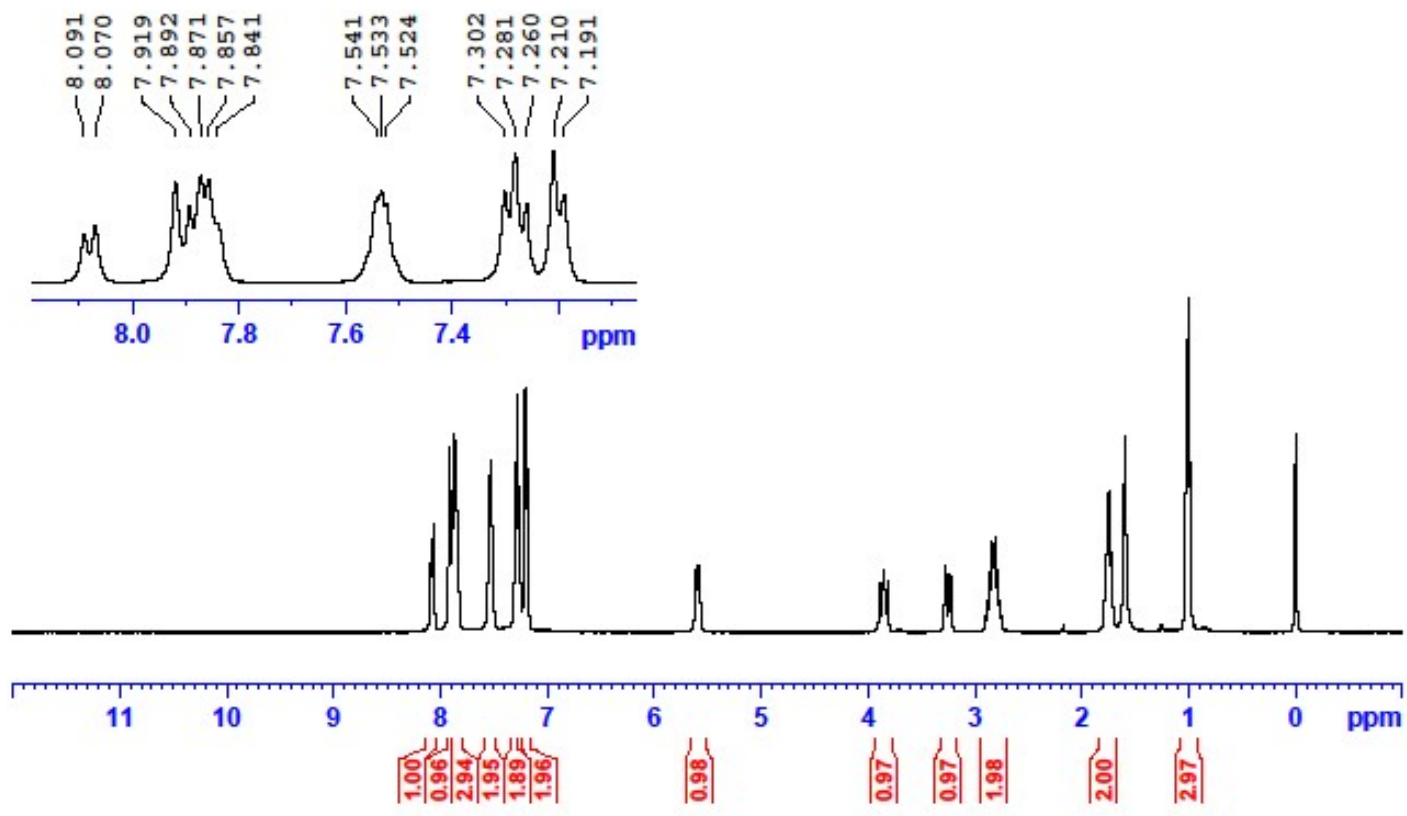

Fig.-3: Proton-NMR Spectrum of Isolated Compound 5a

Table-3: ${ }^{1} \mathrm{H}$ NMR Spectral Data for Isolated Compound (5a-5h) ppm $(\delta)$

\begin{tabular}{c|c|c|c|c|c|c|c|c}
\hline Entry & $5 \mathrm{a}$ & $5 \mathrm{~b}$ & $5 \mathrm{c}$ & $5 \mathrm{~d}$ & $5 \mathrm{e}$ & $5 \mathrm{f}$ & $5 \mathrm{~g}$ & $5 \mathrm{~h}$ \\
\hline $\mathrm{H}-4 \mathrm{a}$ & 3.25 & 3.18 & 3.22 & 3.21 & 3.26 & 3.14 & 3.18 & 3.24 \\
\hline $\mathrm{H}-4 \mathrm{~b}$ & 3.85 & 3.77 & 3.83 & 3.89 & 3.75 & 3.78 & 3.80 & 3.84 \\
\hline $\mathrm{H}-5 \mathrm{a}$ & 5.59 & 5.97 & 5.78 & 5.64 & 5.79 & 5.94 & 5.75 & 5.83 \\
\hline $\mathrm{Ar}-\mathrm{H}$ & $7.19-$ & $7.08-$ & $7.12-$ & $7.06-$ & $7.12-$ & $7.09-$ & $7.04-$ & $7.16-$ \\
& 8.09 & 8.08 & 8.18 & 7.99 & 8.01 & 8.05 & 8.02 & 8.12 \\
\hline $\mathrm{CH}_{2}$ & $1.725-$ & $1.582-$ & $1.625-$ & $1.658-$ & $1.710-$ & $1.728-$ & $1.710-$ & $1.732-$ \\
& 1.780 & 1.821 & 1.820 & 1.825 & 1.792 & 1.801 & 1.808 & 1.810 \\
\hline $\mathrm{CH}_{2}$ & $2.756-$ & $2.815-$ & $2.764-$ & $2.782-$ & $2.782-$ & $2.689-$ & $2.710-$ & $2.764-$ \\
& 2.900 & 2.983 & 2.938 & 2.938 & 2.899 & 2.912 & 2.855 & 2.882 \\
\hline $\mathrm{CH}_{3}$ & $1.008-$ & $1.055-$ & $1.006-$ & $1.038-$ & $1.008-$ & - & $1.012-$ & $1.028-$ \\
& 1.026 & 1.073 & 1.028 & 1.022 & 1.062 & & 1.052 & 1.052 \\
\hline $\mathrm{CH}_{3}$ & - & - & - & - & 2.35 & - & - & - \\
\hline $\mathrm{OCH}_{3}$ & - & - & - & - & - & 3.73 & - & - \\
\hline
\end{tabular}

The ${ }^{13} \mathrm{C}$ NMR spectrum of compound 5a shows that the ${ }^{13} \mathrm{C}$ resonance observed at $171.61 \mathrm{ppm}$ is attributed to $\mathrm{C}=\mathrm{O}$ group of butane moiety in the pyrazoline compound. The ${ }^{13} \mathrm{C}$ resonance observed at $153.52 \mathrm{ppm}$ which indicates the presence of $\mathrm{C}=\mathrm{N}$ group of pyrazole ring in the pyrazoline compound. The ${ }^{13} \mathrm{C}$ resonance observed at $59.63 \mathrm{ppm}$ is due to the presence of $\mathrm{C}-5$ carbon of pyrazole ring in pyrazoline 
RASĀYAN J. Chem.

Vol. 13 | No. 2 |1199-1214| April - June | 2020

compound. The ${ }^{13} \mathrm{C}$ resonance observed at $41.95 \mathrm{ppm}$ which is attributed to the presence of C-4 carbon of pyrazole ring in pyrazoline compound. The ${ }^{13} \mathrm{C}$ resonance observed at $36.17 \mathrm{ppm}$ which indicates the presence of C-2' carbon of pyrazole ring in pyrazoline compound. The ${ }^{13} \mathrm{C}$ resonance observed at 18.39 ppm which is unambiguously assigned the presence of C-3' carbon of butane moiety in pyrazoline compound. The ${ }^{13} \mathrm{C}$ resonance observed at $14.04 \mathrm{ppm}$ which is due to the presence of $\mathrm{CH}_{3}$ group of butane moiety in pyrazoline compound. The aromatic carbons are appeared at in the range of $123.39-$ $129.10 \mathrm{ppm}$. The other ${ }^{13} \mathrm{C}$ signals $133.02,133.40,134.28$ and $140.40 \mathrm{ppm}$ are the presence of ipso carbons From the Carbon-NMR spectral results, the structures of the synthesized compounds were confirmed. The other compounds (5a-5h) ${ }^{13} \mathrm{C}$ NMR spectral data values are shown in Table- 4 .

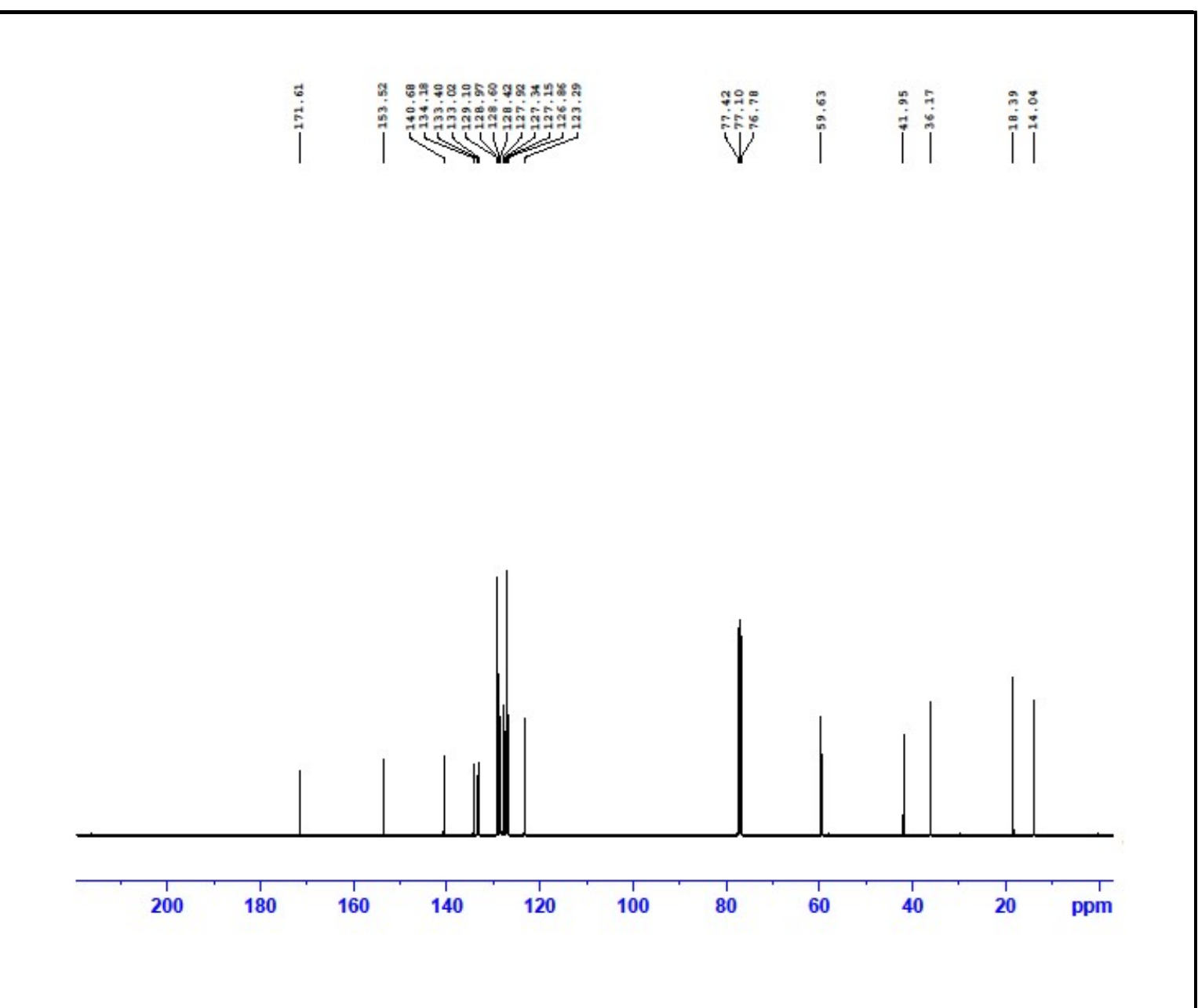

Fig.-4: Carbon-NMR Spectral Data of Isolated Compound 5a

Table-4: ${ }^{13} \mathrm{C}$ NMR Spectral Data of Isolated Compound (5a-5h)ppm $(\delta)$

\begin{tabular}{c|c|c|c|c|c|c|c|c}
\hline Entry & $5 \mathrm{a}$ & $5 \mathrm{~b}$ & $5 \mathrm{c}$ & $5 \mathrm{~d}$ & $5 \mathrm{e}$ & $5 \mathrm{f}$ & $5 \mathrm{~g}$ & $5 \mathrm{~h}$ \\
\hline $\mathrm{C}=\mathrm{O}$ & 171.61 & 171.55 & 172.66 & 172.18 & 171.98 & 172.04 & 171.87 & 171.02 \\
\hline $\mathrm{C}=\mathrm{N}$ & 153.52 & 153.96 & 154.25 & 153.98 & 153.75 & 153.99 & 153.84 & 153.78 \\
\hline $\mathrm{C}-5$ & 59.63 & 58.36 & 58.98 & 59.42 & 59.18 & 59.36 & 59.61 & 59.58 \\
\hline $\mathrm{C}-4$ & 41.95 & 41.28 & 41.89 & 41.91 & 41.57 & 41.82 & 41.39 & 41.67 \\
\hline $\mathrm{C}-2$ & 36.17 & 36.20 & 36.34 & 36.84 & 36.73 & 36.02 & 36.54 & 36.32 \\
\hline $\mathrm{C}-3$ & 18.39 & 18.65 & 18.93 & 18.82 & 18.57 & 18.63 & 18.35 & 18.52 \\
\hline $\mathrm{CH}_{3}$ & 14.04 & 14.16 & 14.08 & 14.25 & 14.12 & 14.29 & 17.08 & 14.19 \\
\hline $\mathrm{Ar}-\mathrm{C}$ & $123.39-$ & $123.26-$ & $121.03-$ & $119.34-$ & $123.07-$ & $124.09-$ & $120.17-$ & $122.04-$ \\
& 129.10 & 131.80 & 128.97 & 128.69 & 131.58 & 132.47 & 131.47 & 131.17 \\
\hline
\end{tabular}


RASĀYAN J. Chem.

Vol. 13 | No. 2 |1199-1214| April - June | 2020

\begin{tabular}{c|c|c|c|c|c|c|c|c}
\hline $\mathrm{CH}_{3}$ & - & - & - & - & 24.22 & - & - & - \\
\hline $\mathrm{OCH}_{3}$ & - & - & - & - & - & 56.87 & - & - \\
\hline
\end{tabular}

Table-5: Physical Characterization of Isolated Compound (5a-5h)

\begin{tabular}{|c|c|c|c|c|c|}
\hline \multirow[t]{2}{*}{ Entry } & \multirow[t]{2}{*}{ M.F } & \multirow[t]{2}{*}{ M.W } & \multirow[t]{2}{*}{ Yield \% } & \multicolumn{2}{|c|}{ Elemental analysis } \\
\hline & & & & Calculated & Found \\
\hline $5 a$ & $\mathrm{C}_{23} \mathrm{H}_{22} \mathrm{~N}_{2} \mathrm{O}$ & 342.43 & 58 & $\begin{array}{c}\mathrm{C}, 80.66 ; \mathrm{H}, 6.42 ; \mathrm{N} \\
8.17 ; \mathrm{O}, 4.66\end{array}$ & $\begin{array}{c}\mathrm{C}, 80.67 ; \mathrm{H}, 6.48, \mathrm{~N}, \\
8.18 ; \mathrm{O}, 4.67\end{array}$ \\
\hline $5 b$ & $\mathrm{C}_{23} \mathrm{H}_{21} \mathrm{FN}_{2} \mathrm{O}$ & 360.42 & 54 & $\begin{array}{c}\mathrm{C}, 76.64 ; \mathrm{H}, 5.82, \mathrm{~F} \\
5.26 ; \mathrm{N}, 7.76 ; \mathrm{O}, 4.43\end{array}$ & $\begin{array}{c}\mathrm{C}, 76.64 ; \mathrm{H}, 5.87 ; \mathrm{F} \\
5.27 ; \mathrm{N}, 7.77 ; \mathrm{O}, 4.44\end{array}$ \\
\hline $5 c$ & $\mathrm{C}_{23} \mathrm{H}_{21} \mathrm{ClN}_{2} \mathrm{O}$ & 376.88 & 59 & $\begin{array}{l}\mathrm{C}, 73.29 ; \mathrm{H}, 5.57 ; \mathrm{Cl} \\
9.40 ; \mathrm{N}, 7.42 ; \mathrm{O}, 4.24\end{array}$ & $\begin{array}{c}\mathrm{C}, 73.30 ; \mathrm{H}, 5.62 ; \mathrm{Cl} \\
9.41 ; \mathrm{O}, 4.25\end{array}$ \\
\hline $5 d$ & $\mathrm{C}_{23} \mathrm{H}_{21} \mathrm{BrN}_{2} \mathrm{O}$ & 421.33 & 56 & $\begin{array}{c}\mathrm{C}, 65.56 ; \mathrm{H}, 4.98 ; \mathrm{Br} \\
18.96 ; \mathrm{N}, 6.64 ; \mathrm{O}, 3.79\end{array}$ & $\begin{array}{c}\mathrm{C}, 65.57 ; \mathrm{H}, 5.02 ; \mathrm{Br} \\
18.96 ; \mathrm{N}, 6.65 ; \mathrm{O}, 3.80\end{array}$ \\
\hline $5 \mathrm{e}$ & $\mathrm{C}_{24} \mathrm{H}_{24} \mathrm{~N}_{2} \mathrm{O}$ & 356.46 & 60 & $\begin{array}{c}\mathrm{C}, 80.86 ; \mathrm{H}, 6.73 ; \mathrm{N}, \\
7.85 ; \mathrm{O}, 4.48\end{array}$ & $\begin{array}{c}\mathrm{C}, 80.87 ; \mathrm{H}, 6.79 ; \mathrm{N}, \\
7.86 ; \mathrm{O}, 4.49\end{array}$ \\
\hline $5 f$ & $\mathrm{C}_{24} \mathrm{H}_{24} \mathrm{~N}_{2} \mathrm{O}_{2}$ & 372.46 & 64 & $\begin{array}{c}\mathrm{C}, 77.38 ; \mathrm{H}, 6.44 ; \mathrm{N}, \\
7.51 ; \mathrm{O}, 8.58\end{array}$ & $\begin{array}{c}\mathrm{C}, 77.39 ; \mathrm{H}, 6.49 ; \mathrm{N}, \\
7.52 ; \mathrm{O}, 8.59\end{array}$ \\
\hline $5 g$ & $\mathrm{C}_{23} \mathrm{H}_{21} \mathrm{~N}_{3} \mathrm{O}_{3}$ & 387.43 & 62 & $\begin{array}{c}\mathrm{C}, 71.29 ; \mathrm{H}, 5.42 ; \mathrm{N} \\
10.84 ; \mathrm{O}, 12.38\end{array}$ & $\begin{array}{c}\mathrm{C}, 71.30 ; \mathrm{H}, 5.46 ; \mathrm{N} \\
10.85 ; \mathrm{O}, 12.39\end{array}$ \\
\hline $5 \mathrm{~h}$ & $\mathrm{C}_{23} \mathrm{H}_{20} \mathrm{Cl}_{2} \mathrm{~N}_{2} \mathrm{O}$ & 411.32 & 65 & $\begin{array}{c}\mathrm{C}, 67.15 ; \mathrm{H}, 4.86 ; \mathrm{Cl}, \\
17.23 ; \mathrm{N}, 6.80 ; \mathrm{O}, 3.88\end{array}$ & $\begin{array}{c}\mathrm{C}, 67.16 ; \mathrm{H}, 4.90 ; \mathrm{Cl}, \\
17.24 ; \mathrm{N}, 6.81 ; \mathrm{O}, 3.89\end{array}$ \\
\hline
\end{tabular}

\section{Antibacterial Activity}

Antibacterial screening of synthesized derivatives (5a-5h) against Gram-positive bacterial species: Staphylococcus aureus, Streptococcus pyogenes and gram-negative species Escherichia coli, Pseudomonas aeruginosa. Antibacterial activity results (Table-6) particularly; compound 5b (Fluoro substitution) exhibited good zone of inhibition $(20 \mathrm{~mm})$ against Staphylococcus aureus and Compound $5 \mathrm{~d}$ (Bromo substitution ) exhibited excellent zone of inhibition $(24 \mathrm{~mm})$ as compared with standard drug ciprofloxacin against Streptococcus pyogenes. Compound 5b (Fluoro substitution) exhibited an excellent zone of inhibition $(24 \mathrm{~mm})$ as compared with standard drug ciprofloxacin against E.coli. Compound $5 \mathrm{~b}$ has an excellent zone of inhibition $(25 \mathrm{~mm})$ compared with the standard drug against Pseudomonas aeruginosa. Finally, the antibacterial result, the electronegativity group ( $\mathrm{F}$ and $\mathrm{Br})$ has excellent activity. The reason is due to the presence of the electronegativity group directly attached to the pyrazole ring moiety of compound $5 \mathrm{~b}$ and $5 \mathrm{~d}$. The electron-withdrawing group attached to the pyrazoline ring portion increased the antibacterial potential against S.pyogenes.
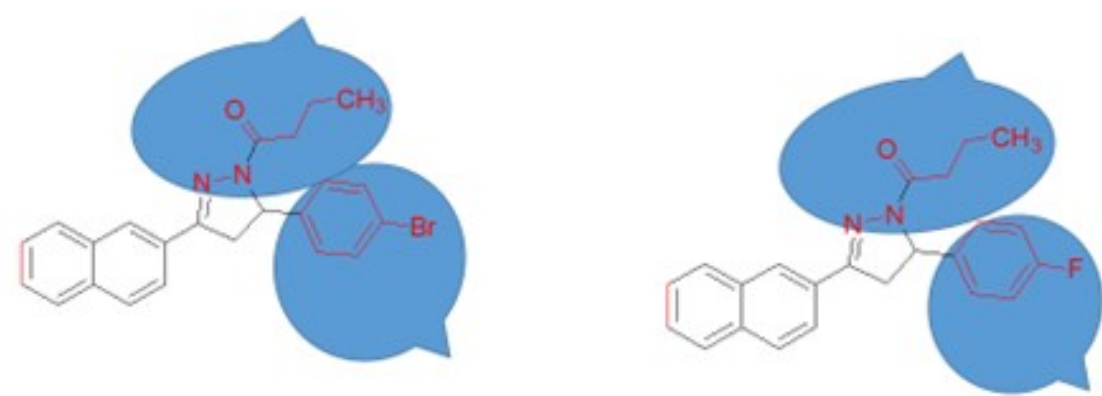

Fig.-5: Chemical Structure of Compound $5 \mathrm{~b}$ and $5 \mathrm{~d}$

Table-6: Antibacterial Activity of Isolated Compound (5a-5h) at $1.0 \mathrm{mg} / \mathrm{ml}$.

\begin{tabular}{c|c|c|c|c}
\hline \multirow{2}{*}{ Entry } & \multicolumn{4}{|c}{ Bacteria } \\
\cline { 2 - 5 } & $\begin{array}{c}\text { Staphylococcus } \\
\text { aureus }\end{array}$ & $\begin{array}{c}\text { Streptococcus } \\
\text { pyogenes }\end{array}$ & $\begin{array}{c}\text { Escherichia } \\
\text { Coli }\end{array}$ & $\begin{array}{c}\text { Pseudomonas } \\
\text { aeruginosa }\end{array}$ \\
\hline $5 \mathrm{a}$ & 15 & 21 & 18 & 16 \\
\hline
\end{tabular}


RASĀYAN J. Chem.

Vol. 13 | No. 2 |1199-1214| April - June | 2020

\begin{tabular}{c|c|c|c|c}
\hline $5 \mathrm{~b}$ & 20 & 22 & 24 & 25 \\
\hline $5 \mathrm{c}$ & 14 & 18 & 16 & 17 \\
\hline $5 \mathrm{~d}$ & 16 & 24 & 20 & 16 \\
\hline $5 \mathrm{e}$ & 16 & 19 & 18 & 16 \\
\hline $5 \mathrm{f}$ & 17 & 18 & 17 & 20 \\
\hline $5 \mathrm{~g}$ & 16 & 16 & 17 & 10 \\
\hline $5 \mathrm{~h}$ & 13 & 15 & 13 & 22 \\
\hline Ciprofloxacin & 26 & 17 & 19 & \\
\hline
\end{tabular}

\section{Antifungal Activity}

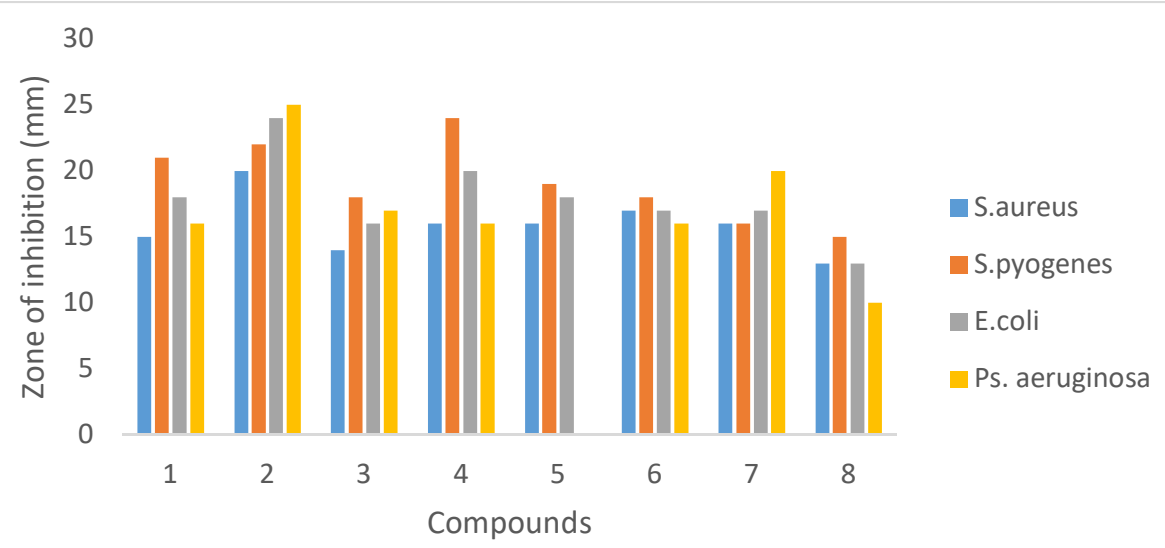

Fig.-6: Antibacterial Activity of Isolated Compound (5a-5h)

Antifungal screening of synthesized derivatives (5a-5h) against candida albicans species was done by agar disk diffusion method. Antifungal results indicated (Table-7) particularly compound $5 \mathrm{~b}$ shown more promising antifungal activity $(14 \mathrm{~mm})$ as compared with standard drug Clotrimazole $(24 \mathrm{~mm})$ while other derivatives are moderately active. The electron-withdrawing group directly attached with pyrazole ring portion of compound $5 \mathrm{~b}$ increased the antifungal potential against C.albicans.

Table-7: Antifungal Activity of Isolated Compound (5a-5h)

\begin{tabular}{c|c}
\hline Entry & Candida albicans \\
\hline $5 \mathrm{a}$ & - \\
\hline $5 \mathrm{~b}$ & 14 \\
\hline $5 \mathrm{c}$ & 12 \\
\hline $5 \mathrm{~d}$ & 13 \\
\hline $5 \mathrm{e}$ & - \\
\hline $5 \mathrm{f}$ & - \\
\hline $5 \mathrm{~g}$ & 11 \\
\hline $5 \mathrm{~h}$ & 10 \\
\hline Clotrimazole & 24 \\
\hline
\end{tabular}

\section{In-silico Molecular Docking Study}

\section{Pyrazoline Compounds (5a-5h), Docked with Bacterial Protein}

Molecular modeling studies were accomplished to investigate the possible bind mode of the synthesized eight pyrazoline derivatives targeting the crystal structure of the bacterial protein 1UAG using Auto dock docking program. From this Table-8, the docking score, conventional hydrogen bond, and hydrophobic contacts such as alkyl and pi-alkyl stacking were provided. Most of the synthesized pyrazoline compounds showed very good interaction with the studied protein. Our synthesized compounds (5a-5h) all are exhibited good binding affinity scores compared with standard drugs. Among the 8 pyrazoline compounds studied with the protein $1 \mathrm{UAG}$, compound $\mathbf{5 b}$ showed a high binding affinity score -9.4 $\mathrm{kcal} / \mathrm{mol}$ compared with standard drug ciprofloxacin $-7.9 \mathrm{kcal} / \mathrm{mol}$. Compound $5 \mathrm{~b}$ has three conventional 
RASĀYAN J. Chem.

Vol. 13 | No. 2 |1199-1214| April - June | 2020

hydrogen bond contact with the residue such as SER A: 415, PHE A: 422, LYS A: 115 . The C=O group of compound $\mathbf{5 b}$ interacted with the active pockets of the enzyme forming hydrogen bonds with SER A: 415 and PHE A: 422 at different distances (2.06 $⿱, 2.70 \AA)$. Also, 4-f substitution benzene ring of compound $5 \mathbf{b}$ interacted with the active pockets of the enzyme forming a hydrogen bond with LYS A: 115 at $2.95 \AA$ distance. The pyrazole ring and benzene ring of compound $5 \mathrm{~b}$ interacted with the active pockets of the enzyme forming hydrophobic contact with ALA A: 414 and LEU A: 416 at different distances of $4.70 \AA, 4.67 \AA$ respectively. Docking score, hydrophobic contact of the derivatives are shown in Table-8. 2D and 3D image of compound $\mathbf{5 b}$ is shown in Fig.-8.

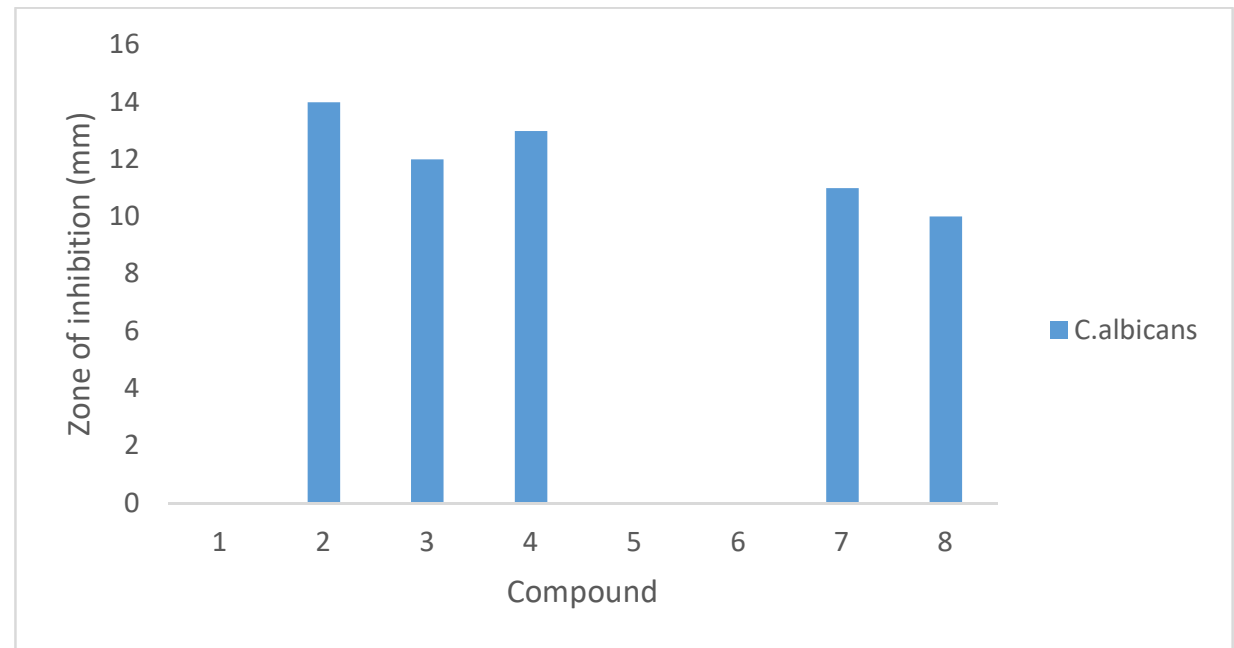

Fig.-7: Antifungal Activity of Isolated Compound (5a-5h)
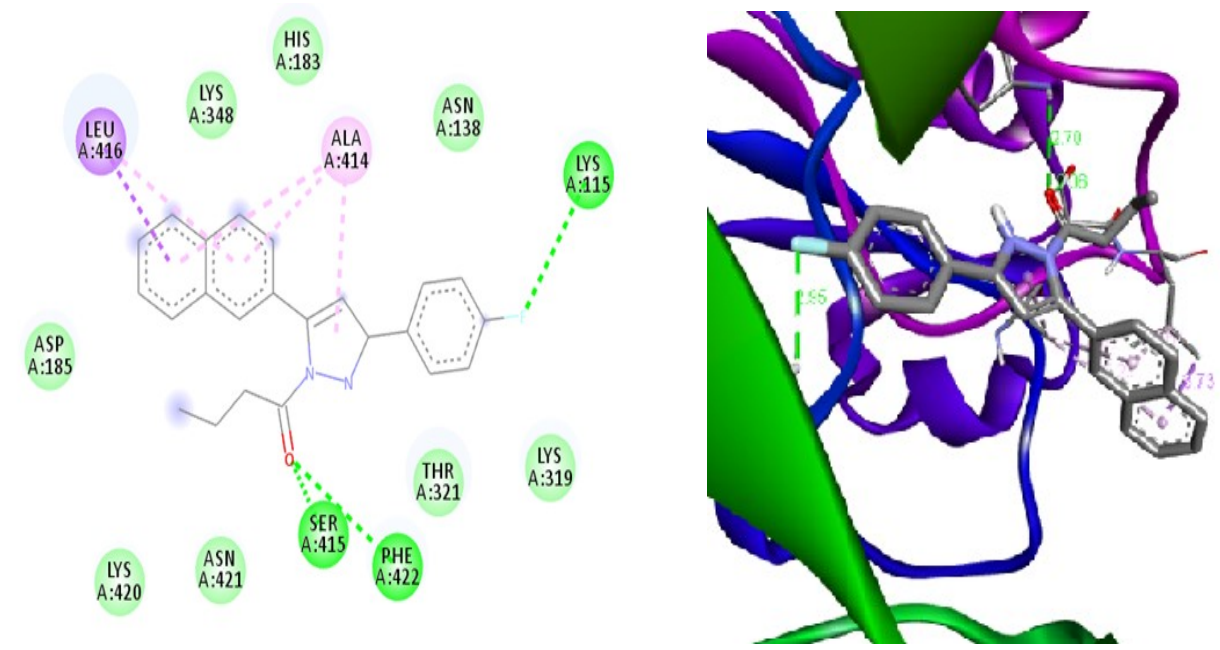

Fig.-8: 2D and 3D Images of Compound 5b

\section{In-vitro Anticancer Activity}

The anticancer activity of synthesized pyrazoline derivatives (5a-5h) was carried out for docking studies using breast cancer protein 1OQA and the results are presented in Table-9. From this result, synthesized compounds (5a-5h) all have a good binding affinity score. Especially, Compound $\mathbf{5 b}$ has a higher binding affinity score when compared with the other derivatives. The benzene ring of compound $5 \mathrm{~b}$ interacted with the active pockets of the enzyme forming hydrophobic contact with the residues PRO A: 59 and PRO A: 103 at different distances (4.62 $\AA, 5.28 \AA$ ). The other compounds docking score, H-bond, and hydrophobic contacts are given in Table-9. The 2D and 3D images of compound 5b shown in Fig.-9. 
RASĀYAN J. Chem.

Vol. 13 | No. 2 |1199-1214| April - June | 2020

Table 8: Molecular Docking Result of Isolated Compound (5a-5h) using Bacterial Protein.

\begin{tabular}{|c|c|c|c|c|c|}
\hline Entry & $\begin{array}{c}\text { Docking } \\
\text { results }\end{array}$ & $\begin{array}{l}\text { Hydrogen } \\
\text { interaction }\end{array}$ & $\begin{array}{c}\text { Length of } \\
\text { Hydrogen bond } \\
\AA\end{array}$ & $\begin{array}{l}\text { Hydrophobic } \\
\text { contact }\end{array}$ & $\begin{array}{l}\text { Hydrophobic } \\
\text { contact bond } \\
\text { length } \AA\end{array}$ \\
\hline $5 a$ & -7.9 & HIS A: 267 & 1.99 & ARG A: 302 & 5.06 \\
\hline $5 b$ & -9.4 & $\begin{array}{c}\text { SER A: 415, PHE } \\
\text { A: 422, LYS A: } \\
115\end{array}$ & $2.06,2.70,2.95$ & $\begin{array}{l}\text { ALA A: } 414, \\
\text { LEU A: } 416\end{array}$ & $4.70,4.67$ \\
\hline $5 c$ & -8.7 & $\begin{array}{c}\text { SER A: } 415 \text {, PHE } \\
\text { A: } 422\end{array}$ & $2.06,2.70$ & $\begin{array}{l}\text { ALA A: } 414, \\
\text { LEU A: } 416\end{array}$ & $4.64,5.29$ \\
\hline $5 d$ & -8.6 & $\begin{array}{c}\text { SER A: } 415 \text {, PHE } \\
\text { A: } 422\end{array}$ & $2.05,2.69$ & $\begin{array}{l}\text { ALA A: } 414, \\
\text { LEU A: } 416\end{array}$ & $4.64,5.29$ \\
\hline $5 e$ & -8.7 & $\begin{array}{c}\text { SER A: } 415 \text {, PHE } \\
\text { A: } 422\end{array}$ & $2.08,2.71$ & $\begin{array}{l}\text { ALA A: } 414, \\
\text { LEU A: } 416\end{array}$ & $4.66,5.24$ \\
\hline $5 f$ & -8.9 & $\begin{array}{c}\text { SER A: } 415, \text { PHE } \\
\text { A: 422, LYS A: } \\
319\end{array}$ & $2.07,2.71,2.53$ & $\begin{array}{l}\text { ALA A: } 414, \\
\text { LEU A: } 416\end{array}$ & $4.70,5.23$ \\
\hline $5 g$ & -8.8 & $\begin{array}{c}\text { SER A: 415, PHE } \\
\text { A: 422, LYS A: } \\
\text { 115, LYS A: } 319\end{array}$ & $\begin{array}{l}2.08,2.70, \\
2.40,2.63\end{array}$ & $\begin{array}{l}\text { ALA A: } 414, \\
\text { LEU A: } 416\end{array}$ & $4.70,5.27$ \\
\hline $5 \mathrm{~h}$ & -7.9 & - & - & $\begin{array}{l}\text { PHE A: } 422, \\
\text { ARG A: } 186\end{array}$ & $5.08,5.01,5.11$ \\
\hline Ciprofloxacin & -7.8 & $\begin{array}{c}\text { HIS A: } 267, \text { ASN } \\
\text { A: } 113\end{array}$ & $2.07,2.15,2.81$ & ALA A: 328 & 4.70 \\
\hline
\end{tabular}

Table-9: Molecular Docking Studies Performed for Pyrazoline Compound (5a-5h) Using Breast Cancer Protein

\begin{tabular}{|c|c|c|c|c|c|}
\hline \multicolumn{6}{|c|}{ 1OQA. } \\
\hline Entry & Docking results & $\begin{array}{c}\text { Conventional } \\
\text { H-Bond }\end{array}$ & $\begin{array}{c}\text { H-B } \\
\text { Bond length } \\
\AA\end{array}$ & $\begin{array}{c}\text { Hydrophobic } \\
\text { Contact } \\
\AA\end{array}$ & $\begin{array}{c}\text { Hydrophobic } \\
\text { Bond length } \\
\AA\end{array}$ \\
\hline $5 a$ & -7.1 & - & - & $\begin{array}{l}\text { PRO A; } 59, \\
\text { PRO A: } 103, \\
\text { ILE A: } 102\end{array}$ & $4.65,5.31,5.48$ \\
\hline $5 b$ & -7.9 & - & - & $\begin{array}{l}\text { PRO A: } 59, \\
\text { PRO A: } 103\end{array}$ & $4.62,5.28$ \\
\hline $5 c$ & -7.3 & - & - & $\begin{array}{l}\text { PRO A: } 59, \\
\text { ILE A: } 103\end{array}$ & $4.61,5.30$ \\
\hline $5 d$ & -7.3 & - & - & $\begin{array}{l}\text { PRO A: } 59, \\
\text { PRO A: } 103, \\
\text { ILE A: } 102\end{array}$ & $4.64,4.62,4.42$ \\
\hline $5 e$ & -7.4 & - & - & $\begin{array}{c}\text { PRO A: } \\
\text { 59,PRO A: } \\
\text { 103, ILE A: } \\
102\end{array}$ & $4.58,5.28,5.46$ \\
\hline $5 f$ & -7.2 & - & - & $\begin{array}{l}\text { PRO A: } 59, \\
\text { PRO A: } 103, \\
\text { ILE A: } 102\end{array}$ & $4.50,5.37,5.43$ \\
\hline $5 g$ & -7.6 & ASP A: 65 & 2.34 & $\begin{array}{c}\text { PRO A: } \\
\text { 103,PRO A: } 59\end{array}$ & $4.60,5.21$ \\
\hline $5 \mathrm{~h}$ & -6.9 & - & - & $\begin{array}{l}\text { PRO A: } 59, \\
\text { PRO A: } 103, \\
\text { ILE A: } 102\end{array}$ & $4.59,4.58,4.66$ \\
\hline
\end{tabular}


RASĀYAN J. Chem.

Vol. 13 | No. 2 |1199-1214| April - June | 2020
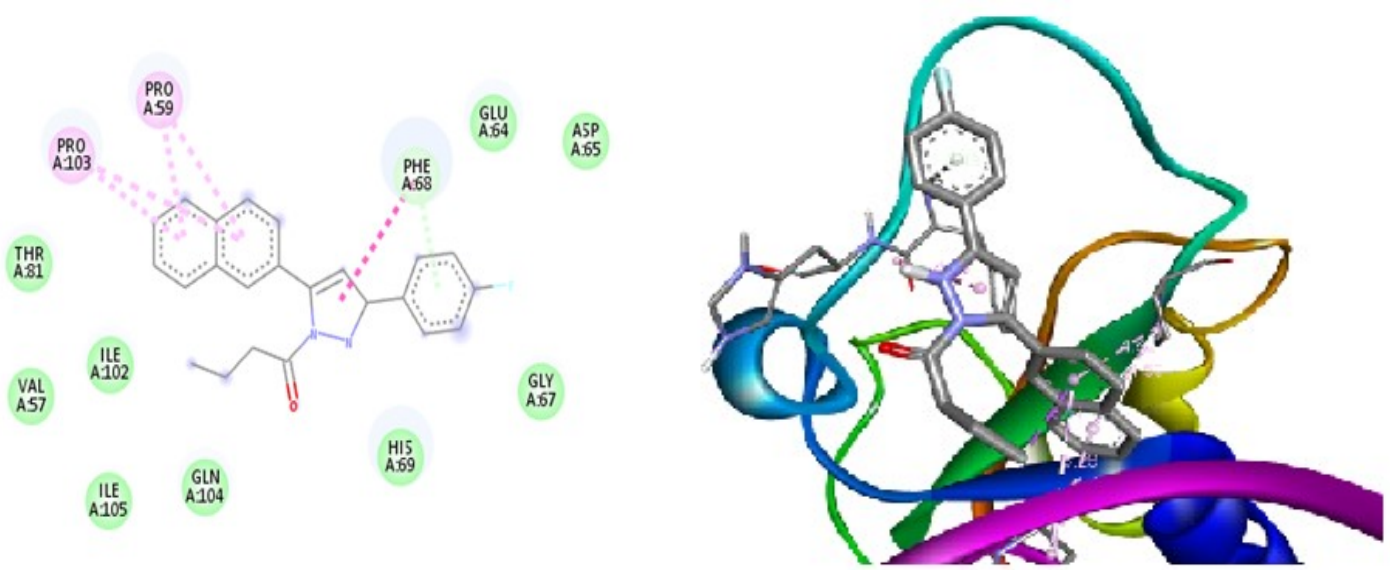

Fig.-9: 2D and 3D Images of Compound 5b

\section{In-silico Druglikness Study}

The target molecules (5a-5h) subjected to druglikness property with the help of Osris program. The values from the program said that the solubility, MW, TPSA, $\log \mathrm{P} o / \mathrm{w}$ and drug score. All the compounds, the target $\mathbf{5} \mathbf{c}$ which have positive value 1.21 in the druglikness property, 0.51 as a drug score with $32.67 \AA$ TPSA and zero violation in Lipinski's rule. All the pyrazoline derivatives have zero violations in Lipinski's rule, have good TPSA and have solubility value between -7 to -5 . The values are predicted from the software program, it was tabulated and given below in Table-10.

\section{In-vitro Anticancer Activity}

\section{MTT Assay}

According to the docking results. The compound $\mathbf{5 b}$ was performed in-vitro anticancer activity against the human breast cancer cell line( MDA MB-231 ) using MTT assay method at various concentrations (100, $50,25,12.5,6.25 \mu \mathrm{g} / \mathrm{ml})$ and the results are presented in Fig.-10 and 11. Anticancer screening results revealed that in general pyrazoline derivatives exhibited good anticanticancer potential against human breast cancer cell line, especially, compound $5 \mathrm{~b}$ act as a moderate activity in all concentrations except $6.25 \mu \mathrm{g} / \mathrm{ml}$ showed good activity and the LC50 value of this compound is $27.76 \pm 0.003 \mu \mathrm{g} / \mathrm{ml}$. Triplicate experimental method was followed and then the mean value was calculated.

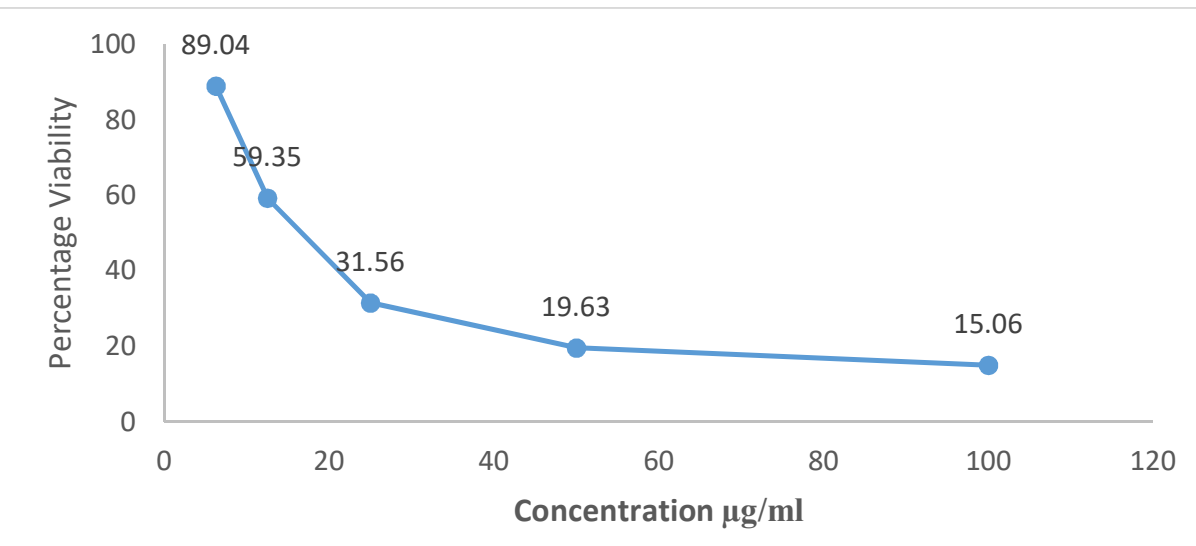

Fig.-10: In-vitro Anticancer Activity Screening for Compound 5b at Low Concentration

Table-10: Druglikness, Toxicity, Surface Area and Lipinski Rule Values of Compound 5a-5h

\begin{tabular}{c|c|c|c|c|c|c|c|c|c}
\hline Compound & Log P & MW & n-HA & n-HD & $\begin{array}{c}\text { n-violation } \\
\text { in rule of } \\
\text { five }\end{array}$ & TPSA & $\begin{array}{c}\text { Solubility } \\
\operatorname{logS}\end{array}$ & Druglikness & $\begin{array}{c}\text { Drug } \\
\text { Score }\end{array}$ \\
\hline $5 \mathrm{a}$ & 5.33 & 342.4 & 3 & 0 & 0 & 32.67 & -5.76 & -0.60 & 0.45 \\
\hline
\end{tabular}


RASĀYAN J. Chem.

Vol. 13 | No. 2 |1199-1214| April - June | 2020

\begin{tabular}{c|c|c|c|c|c|c|c|c|c}
\hline $5 \mathrm{~b}$ & 5.43 & 360.4 & 3 & 0 & 0 & 32.67 & -6.08 & -0.34 & 0.45 \\
\hline $5 \mathrm{c}$ & 5.94 & 376.8 & 3 & 0 & 0 & 32.67 & -6.50 & 1.21 & 0.51 \\
\hline $5 \mathrm{~d}$ & 6.06 & 421.3 & 3 & 0 & 0 & 32.67 & -6.60 & -1.85 & 0.31 \\
\hline $5 \mathrm{e}$ & 5.68 & 356.4 & 3 & 0 & 0 & 32.67 & -6.11 & -1.88 & 0.35 \\
\hline $5 \mathrm{f}$ & 5.26 & 372.4 & 4 & 0 & 0 & 41.90 & -5.78 & -0.39 & 0.46 \\
\hline $5 \mathrm{~g}$ & 5.42 & 386.4 & 4 & 1 & 0 & 72.98 & -6.22 & -0.82 & 0.41 \\
\hline $5 \mathrm{~h}$ & 6.54 & 411.3 & 3 & 0 & 0 & 32.67 & -7.23 & -1.09 & 0.32 \\
\hline
\end{tabular}

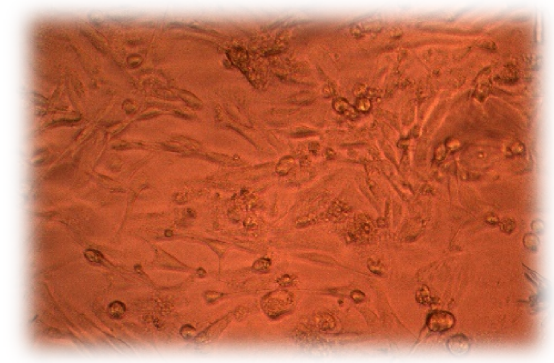

(a)

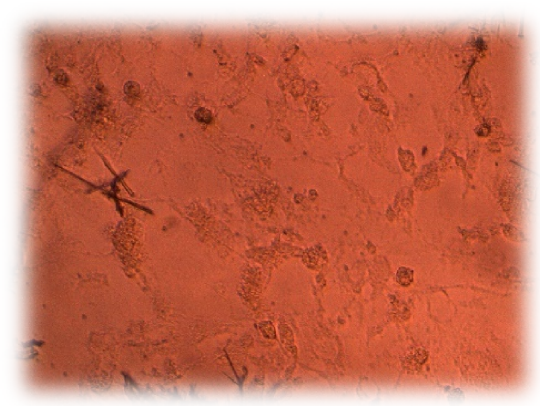

(c)

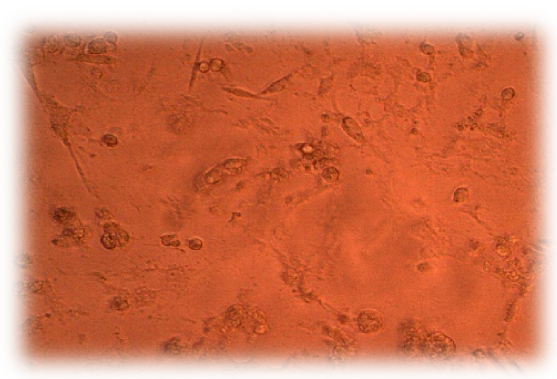

(b)

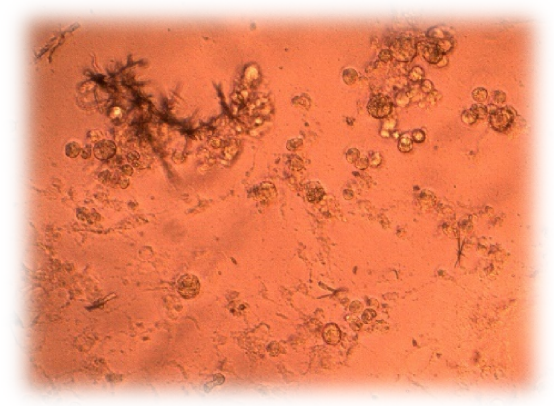

(d)

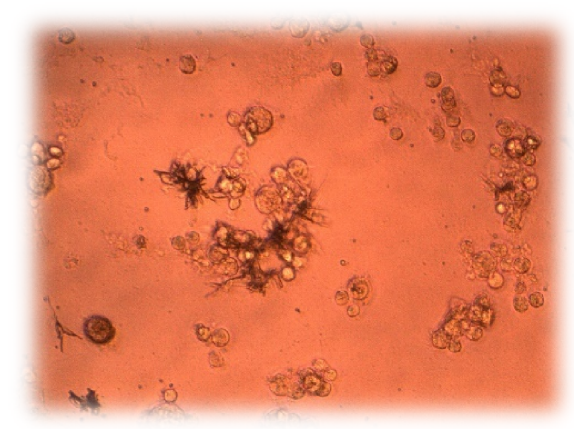

(e)

Fig.-11: In-vitro Anticancer Activity of Compound 5i. MDA-MB-231 Cells were incubated for 48 hours in presence of (i) $5 \mathrm{i}$ at $6.25 \mu \mathrm{g} / \mathrm{ml}$ (ii) $5 \mathrm{i}$ at $12.5 \mu \mathrm{g} / \mathrm{ml}$ (iii) $5 \mathrm{i}$ at $25 \mu \mathrm{g} / \mathrm{ml} \quad$ (iv) $5 \mathrm{i}$ at $50 \mu \mathrm{g} / \mathrm{ml}$ (v) $5 \mathrm{i}$ at $100 \mu \mathrm{g} / \mathrm{ml}$

\section{CONCLUSION}

Summarizing, Eight novel proponone pyrazole compounds were synthesized and characterized by phiochemical and spectral data was found in good agreement with the assigned molecular structures. The in-vitro antimicrobial screening of synthesized compounds indicated $\mathbf{5 b}$ and $\mathbf{5 d}$ exhibited appreciable antimicrobial potential. The anticancer screening results demonstrated that compound $\mathbf{5 b}$ (LC50 = $27.76 \pm 0.003 \mu \mathrm{g} / \mathrm{ml}$ ) is the most active one against MDA-MB-231 cancer cell line. Molecular docking studies indicated the compound $\mathbf{5 b}$ being the most active molecule has the maximum hydrogen bond interaction(three) and pi-pi stacking network among pyrazoline derivatives. The synthesized compounds may exhibit their antimicrobial and anticancer activity by the inhibition of enzymes 1OQA and MDA- 
MB-231 respectively. Finally, the obtained antimicrobial and anticancer data makes such type of compounds a fruitful matrix for further development of more potent and selective anticancer and/or antimicrobial agents. In particular the compound $\mathbf{5 b}$ could be considered as a possible dual antimicrobialanticancer candidate that deserves further investigation and derivatization to explore the scope and limitation of its biological activities.

\section{ACKNOWLEDGMENT}

We thank the Biogenix Research Center for conducting the MDA MB-231 Cell line anticancer MTT assay for our compound $\mathbf{5 b}$.

\section{REFERENCES}

1. L.Siva Sanker Reddy, M.Bhagavan Raju and C.Sridhar, International Journal of Pharmacy and Pharmaceutical Sciences, 8(1), 247(2016)

2. L.G.Jose,E.S.Chad, W. Tanja , B.Reto , A.T.Farial, W. David, Todd Bet al. European Journal of Medicinal Chemistry, 42, 552(2007), DOI:10.1016/j.ejmech.2006.11.006

3. P.P. Kattimani, R.R. Kamble, M.Y. Kariduraganavar, A. Dorababu, R.K. Hunnur, European Journal of Medicinal Chemistry, 62, 232(2013), DOI:10.1016/j.ejmech.2013.01.004

4. T. Nasr, S. Bondock, M. Youns, European Journal of Medicinal Chemistry,76, 539(2014), DOI: 10.1016/j.ejmech.2014.02.026

5. S. Rathinamanivannan, K. Megha, Raja Chinnamanayakar, Ashok Kumar and M.R.Ezhilarasi. Asian Journal of Chemistry,31(10), 3191(2019), DOI:10.14233/ajchem.2019.22082

6. R. Ali, Ahmed, El-Bendary, R. Eman, A. Mariam, Ghaly, Shehata, A. Ihsan, European Journal of Medicinal Chemistry, 75, 492(2014), DOI:10.1016/j.ejmech.2013.12.010

7. Raja Chinnamanayakar, M. REzhilarasi, B. Prabha and M. Kulandhaivel M.Asian Journal of Pharmaceutical anf Clinical Research, 12(3), 311(2019), DOI:10.22159/ajpcr.2019.v12i3.30481

8. H. Doshi, S. Thakkar, P. Khirsariya, M. C. Thakur, A. Ray, Applied Biochemistry and Biotechnoly, 175, 1700(2015), DOI:10.1007/s12010-014-1399-8

9. K. S. Atwal, G. C.Rovnyak, S. D.Kimball, D. M. Floyd, S. Moreland, B. N. Swanson, J. Z. Gougoutas, J. Schwart, K. M.Smillie and M. F. Malley, Journal of Medicinal Chemistry, 33, 2629(1990), DOI:10.1021/jm00171a044

10. K.S. Nimavat, K. H. popat, S. L. Vasoya and H. S. Joshi, Indian Journal of heterocyclic Chemistry, 12,217(2003)

11. B. B. Chvan, A. S. Gadekar, P. P. Mehta, P. K. Vawhal, A. K. Kolsure and A. R. Chabukswar, Asian Journal of Biomedical and Pharmaceutical Science, 6, 1 (2016)

12. Vijayakumar Kanagarajan, Muthuvel Ramanathan Ezhilarasi and Mannathusamy Gopalakrishnan. Organic and Medicinal Chemistry Letters, 1, 8(2011), DOI:10.1186/2191-2858-1-8

13. E. C. Taylor, H. Patel, and H. Kumar, Tetrahedron , 48, 8089(1992), DOI:10.1016/S00404020(01)80479-8

14. B. S. Holla, P. M. Akberali, and M. K. Shivananda, II Formaco, 55, 256(2000) DOI:10.1016/j.wear.2005.10.001

15. E. Bansal, V. K.Srivastava, and A. Kumar, European Journal of Medicinal Chemistry, 36, 81(2001), DOI: $10.1016 / \mathrm{s} 0223-5234(00) 01179-\mathrm{x}$

16. F. Manna, F. Chimenti, R. Fioravanti, A. Bolasco, D. Secci, P. Chimenti, C. Ferlini, and G. Scambia, Bioorganic Medicinal Chemistry Letters, 15, 4632(2005),DOI: 10.22270/ijdra.v2i4.153

17. J. H. Ahn, H. M. Kim, S. H. Jung, S. K. Kang, K. R. Kim, S. D. Rhee, S. D. Yang, H. G. Cheon, and S. S. Kim, Bioorganic Medicinal Chemistry Letters, 14, 4461(2004), DOI:10.22270/ijdra.v2i4.153

18. R. Sharma, P. Samadhiya, S. D. Srivastava, Journal of Serbian Chemical Society,77,17,(2012), DOI: $10.2298 /$ JSC100924152S

19. A. Mashrai, A. M. Dar, S. Mir and Shamsuzzaman, Medicinal Chemistry (Los Angels), 6,280(2016), DOI: $10.4172 / 2161-0444.1000358$

20. M. Idrees, S. Kola and N. J. Siddiqui. Rasayan Journal of Chemistry, 12(4),1725(2019), DOI: $10.31788 /$ RJC.2019.1245467 
RASĀYAN J. Chem.

Vol. 13 | No. 2 |1199-1214| April - June | 2020

21. Mohammed Karabacak, Mehlika Dilek Altintop.Halil Ibrahim Ciftci, Ryoko kogo, Masami Otsuka, Mikako Fujita and Ahmet Ozdemir. Molecules, 20, 19066(2015), DOI:10.3390/molecules201019066

22. M. R. Ezhilarasi, B. Prabha, and T. Santhi, Rasayan Journal of Chemistry, 8(1), 71(2015)

23. T. Hou, J. Wang, W. Zhang and X. Xu , Journal of Chemical Information and Modeling, 47(2), 460(2007)

24. P. D.Leeson and A. M. Davis, Journal of Medicinal Chemistry, 47(25), 6338(2004), DOI: $10.1021 / \mathrm{jm} 049717 \mathrm{~d}$

25. D. A. Smith and E. F. Schmid, Journal of Current Opinion in Drug Discovery and Development, 9(1),38(2006)

26. Kathryn A. Loving, Andy Lin and C. Alan, Journal of PLOS Computatational Biology, 10(9), e 1003875(2014), DOI:10.1371/journal.pcbi.1003875

27. Joanne Bowes, Andrew J. Brown, Jacques Hamon, Wolfgang Jarolimek, Arun Srithar, Gareth Waldronand Steven Whitebread, Journal of Nature Reviews Drug Discovery,11(12),909(2012), DOI: $10.1038 / \mathrm{nrd} 3845$

28. A. Salma, El Sherbeni, F. Tarek, El Moselhy, Chemistry Research Journal ,2(5),131(2017)

29. A. B. Senthieel Khumar, M. R. Ezhilarasi and B. Prabha, Asian Journal of Chemistry,. 30(4), 741(2018), DOI:10.14233/ajchem.2018.20913

30. Raja Chinnamanayakar, M. R. Ezhilarasi, B. Prabha and Kulandhaivel, Asian Journal of Chemistry, 30(4), 783(2018), DOI:10.14233/ajchem.2018.20992

31. B. Nathiya, M. R. Ezhilarasi, B. Prabha, C. Raja and M. Kulandhaivel, European Journal of Pharmaceutical and Medicinal Research, 4(2),769(2017)

32. R. Surendra Kumar, Ibrahim A. Arif, Anis Ahamed, Akbar Idhayadhulla. Saudi Journal of Biological Sciences, 23(5),614(2016), DOI:10.1016/j.sjbs.2015.07.005

33. V. Kanagarajan, M. R. Ezhilarasi, M. Gopalakrishnan, Spectrachimica Acta Part A: Molecular and Biomolecular Spectroscopy, 78, 635(2011), DOI:10.1016/j.saa.2010.11.038

34. R. Sri Dharani, R. Ranjitha, R. Sripathi, K.S. Ali Muhammad, S. Ravi, Asian Journal of Pharmaceutical and Clinical Research, 9 (5), 121(2016), DOI:10.22159/ajpcr.2016.v9i5.12693

35. C. Perez, M. Pauli, and P. Bazerque, Acta Biologiae et Medicinae Experimentails, 15, 113(1990), DOI: $10.1016 / 0378-8741(94) 90097-3$

36. M. Shivanand, P. Vijaya Kumar and V. Ravikumar, Rasayan Journal of Chemistry, 12(4),1810(2019), DOI:10.31788/RJC.2019.1245375

37. M. Idrees, Y. G. Bodkhe, N. J. Siddiqui and S. Kola. Rasayan Journal of Chemistry, 13(1),291(2020), DOI: $10.31788 /$ RJC.2020.1315593

38. B. Laura, Talarico., Zibetti, G.M. Rosiane ,C.S.Paula, Luis, A. Faria ,Scolaro, Duarte, E.R. Maria, Noseda, D. Miguel, A. PujolsCarlos, Damonte, B. Elsa , International Journal of Biological Macromolecules, 34, 63(2004), DOI:10.1016/j.ijbiomac.2004.03.002

[RJC-5495/2019] 